\title{
INSTAGRAM USE TO ENHANCE ABILITY IN WRITING DESCRIPTIVE TEXTS
}

\author{
Soviyah \\ Universitas Ahmad Dahlan, Indonesia \\ E-mail: soviyah@pbi.uad.ac.id \\ Diana Rahayu Etikaningsih \\ Universitas Ahmad Dahlan, Indonesia \\ E-mail: dianarahayuetikaningsih@gmail.com
}

APA Citation: Soviyah, S., \& Etikaningsih, D. R. (2018). Instagram use to enhance ability in writing descriptive texts. Indonesian EFL Journal, 4(2), 32-38. doi: 10.25134/ieflj.v4i2.1373.

Published: 01-07-2018

\begin{abstract}
Technology is changing the world we live in. It affects the way people see, think, and learn their environment and communicate with others. In the educational field, there have been previous studies revealing the positive attitudes toward the use of mobile devices and applications. However, the empirical studies of the practice of how to use a specific mobile device and application effectively are done in a limited scale. Taking the experimental research method, this study investigated the effectiveness of the use of Instagram application on the students' performance in writing descriptive texts. The main research question was centred around whether there was significant difference in the ability of writing descriptive text between students who were taught using Instagram and those who aren't. Involving random sampling technique, this study involved 50 students of a private high school in Yogyakarta as the research sample. The empirical data were collected through pre and post tests. The data were analyzed quantitatively applying t-test computation and descriptive analysis. Results of the study indicate that there is significant difference in students writing score between those taught using Instagram and those who aren't. In conclusion, teaching students writing by using Instagram pictures are more effective than teaching without using Instagram pictures. In other words, the use of Instagram is effective in teaching writing descriptive texts.
\end{abstract}

Keywords: technology; Instagram; experimental research; writing descriptive text.

\section{INTRODUCTION}

English becomes one of the languages that has a big role in the world. It is known as the language of international communication. Due to this status, people have been learning and trying to acquire it so that they are able to communicate with more people worldwide and use it in their daily lives as well.

In Indonesia, English is one of the subjects taught in schools. It's a compulsory subject in junior and senior high schools with an annual national exam tested nationally. In elementary school level, English used to be a local content subject. Now, it belongs into an extracurricular subjects group together with scouting, art, and music. In terms of the materials given, schools students are given the four skills based English material, i.e. listening, speaking, reading, and speaking.
These four skills are presented in balance, meaning that no skill is given more attention than the others.

Talking about writing skill, it's been long said that among the four skills taught, writing is considered the most important skill. It's said so as it helps develop student's critical thinking skills and helps them understand and communicate complicated ideas (Allyn, 2015). Dantes (2013) states that writing becomes one of the most important aspects of the language skills since it helps students expand the other language macro skills without them being aware of doing it. During a writing process, in addition to having discussion with friends and or teachers, students usually need to explore their ideas by reading some articles, journals or books. The students do these activities 
altogether intensively. In other words, they practice listening, speaking and reading at the same time. This illustrates how writing can help improve the other skills. Besides the language macro skills learned through writing, a writing process has also been recognized as the effective way of learning English micro such as idioms, grammar and structure, pronunciation and vocabulary (Sattayatham and Rafanapinyowong in Aryanti (2016). In sum, writing is beneficial and effective tool to learn both language macro and micro skills.

Unfortunately, even though writing takes an important role and becomes a fundamental skill for students' academic life, learners commonly find it as the most difficult skill to acquire. They have difficulties in mastering it because of some factors such as vocabulary and grammar. As we know, in its process, writing demands learners to have ample vocabulary mastery, as with limited vocabulary, a learner will express only very limited ideas in her writing. It's the same case with grammar aspect. Bad grammar competency will make the writing process feel difficult to learners. Based on the explanation, it can be said that vocabulary and grammar together hold a vital role in a writing process and make a writing process successful. And thus, limited mastery of the two will cause writing process troublesome. Another writing difficulty faced by the students is related with the language gap between English and Indonesian. The differences English and Indonesian have in most of their aspects have become the source of writing mistakes among the Indonesian students who are foreigners to English. Not always being fully aware of the differences, majority of the students in Indonesia usually make mistakes in writing because they do mixing the grammar blindly and translating the words directly. They do not pay much attention to the differences between English and Indonesian when writing, however in fact, English and Indonesian are a lot different in terms of structural, grammatical, terms and styles.

This research began when the researcher got involved in the English learning process in a private high school in Yogyakarta. During the involvement, the researcher noticed that the students found difficulties in learning writing, especially writing descriptive text, which becomes the main type of text tenth graders of high school level are supposed to acquire. To dig out the students' problems in writing, in addition to an informal interview, the researcher made a classroom observation. The classroom observation results revealed that during the lesson the learning situation felt boring and unattractive and failed to make the students participate actively. When asked to write, the students showed reluctance and unwillingness. The learning method used was also conventional with the English textbook playing the main role. All these series of situations resulted in the quite low average score of the students' writing test, which was under 70 .

Meanwhile, the results of the interview complemented the classroom observation results. From the interview, it was found out that the students felt confused when writing because they did not know how to start writing and how to express their ideas. Furthermore, they said they were short of motivation. They complained of the process of learning writing which they perceived as dull and boring with repeated similar ways of learning. Also, they tended to fail finding the relevance of learning writing with their real lives. Furthermore, they said that they wanted something new and refreshing during the learning process of writing.

In spite of the apparent problems and difficulties, there was an interesting finding during the observation. It was when the researcher found out that nearly all of the students seemed to have their own hand phones. Even though they did not use them all the time, especially when the lesson was running, whenever there was a chance, they used the hand phones to catch up with the up dated news and information about their friends. During the interview, when asked what application they used the most, all of the respondents said Instagram, Whatsapp and Line. Furthermore, when asked to choose one favorit application among these three, they chose Instagram and agreed that they liked it more because they could show and see their friends' photos through it. Based on this 
finding, the researcher tried to get the two points connected, i.e. students' writing problems and Instagram application. Thus this study aims at finding out the effectiveness of Instagram use in enhancing the students' ability in writing descriptive texts.

\section{Instagram}

Literally, Instagram is a portmanteau word of instant camera and telegram. These two words blend the sounds and combine the meanings into Instagram. Instagram is a fun and quick way to share people's life with their friends through a series of pictures. Instagram is a relatively new form of communication where users can easily share their updates by taking photos or videos (Yuheng $\mathrm{Hu}, 2014$ ). Using a mobile phone, Instagram allows users to snap a picture and share it to others. Users only need to snap a photo, then choose a filter to transform the image and keep it around forever as a memory (Instagram , 2017). In addition, users can also add text to give information about the pictures or videos shared. In terms of who use it and for what function, Instagram can be used by everyone all over the world in order to post any updates or information, share photos or videos, and chat or argue with other Instagram users.

Historically, Instagram was founded by duo Kevin systrom and Mike Krieger. It was first meant to help Kevin Systrom work with some coding activities. Together with Mike Krieger, it was then developed into an open, and user friendly application possibly and easily used by public. In its development, instagram had undergone various stages. Officially made into public in October 2010, instagram was at first introduced as application software only for iPhones. However, in April 2012, it welcomed the Android world to join in. In the same year, precisely in September 2012 the gigantic Facebook bought it for one billion dollars.

In terms of number of the users, instagram has attracted many users and obtained fame worldwide. Less than two years from its launch date, there had been over 100 million active users as of April 2012. It got more popularity as there were over 600 million as of April 2017. Currently, instagram has 90 million active users monthly.
Seen from features it offers, based on ASCPL (2014), Instagram provides several features for users as to upload photos to multiple social media networks instantly such as Facebook, Twitter, etc; follow special interest groups like fishing, beauty, cars, sports, etc.; follow other members such as celebrities and friends; and highlight and share important events in life through photography.

\section{Instagram and language learning}

As previously explained, Instagram is interesting and appealing with its features to support people's communication needs. Moreover, Instagram and its supporting features can also be used as a medium in learning process related activities (Listiani, 2016). Among other features of instagram that can be used to support language learning process are:

1) Photo and Video Sharing

Instagram enables users to take pictures or videos using the application or to use photos/videos already existing in the user's camera album. In addition, users can add a caption in the form of words, sentences or paragraphs in their photo/video. The caption itself can give information about what is actually going on in relation to the uploaded photo/video. If it is used in a language learning process, this feature of uploading and captioning pictures/videos is especially very relevant to help language learners learn how to write effectively in a language. In other words, intagram is useful to help learners learn writing.

2) Social Network

Instagram, like any other social network, is based on social life just like having friends or it's called followers in Instagram. In Instagram, users can be friends with others by 'following' them. Through this feature, users can interact with other people trough loving and leaving comments to other users using icons provided. Besides, users can also communicate using direct message feature.

In addition to communication between a user-to-user based, users of instagram can also make a community. Under community based setting, instagram users gather and share pictures, information and knowledge with other users who have the same passion and 
interest, such as travelling, craft, food, sports, automobiles, and other examples of hobbies and leisure. These users of the same interest communicate constantly. This way, instagram is very possibly providing service for language educational purpose since it facilitates learners to learn how to chat and talk and speak in a language effectively.

In sum, the two main features of instagram (photo and video sharing and social networking) are surely a good resource to make use of in a teaching and learning setting, particularly in learning writing. It is due to the fact that by writing captions of their uploaded pictures or videos and direct or chat messages during the instagram communication taking place, users learn to think and communicate in the form of writing - their feelings and opinions to other people in an effective and systematic way. This way, it's apparent how features of instagram have made it possible to use in the learning process of writing.

\section{METHOD}

With the aim of finding out the effectiveness of using instagram to teach students writing descriptive text, this study was categorized into an experimental research. The research setting was in a private high school in Yogyakarta and done in late of 2017. This research involved 6 classes of level X students who were divided into two groups namely experimental and control groups. Each group consisted of 25 students. In choosing the groups, it was done randomly using random sampling technique.

For the research variables, there were two variables used, namely the independent variable and dependent variable. In this case, using instagram to teach writing was the independent variable $(\mathrm{X})$ and students' writing mastery was the dependent variable (Y).

This research used a writing test as the data collecting technique. There were two writing tests given, i.e. a pre test and a post test. The writing test was also serving as the research instrument. Meanwhile for the data analysis, it was done quantitatively by applying the descriptive analysis, and inferential analysis. To test the hypothesis, that there was significant different in students'

writing ability between those who taught by using instagram and those who taught without using instagram, it was done a t-test.

As an experimental research, this study involved two groups, namely experimental and control groups. The two groups were given different treatment. The experimental group was taught by using instagram while the control group was taught without instagram. However, the material given to both experimental and control groups were the same. In term of test, prior to the treatment, both groups were given the same pre test. After the treatment, a post test of the same test instrument was given to the two groups. The results of the pre test and post test were compared to each other to find whether there was significant difference or not.

In addition to two meetings as the pre-test and post-test sessions, the treatment was given four times starting from on $15^{\text {th }}$ September 2017 to $13^{\text {th }}$ October 2017. The learning material was based on the school syllabus, which was descriptive text. The instagram used as the learning media in which the researcher took some pictures from instagram to use during the lesson. In meeting 1 and 2 the pictures taken were related to places, while in meeting 3 and 4 the pictures used were about people and friends.

The researcher acted as the teacher. She did the teaching by following the lesson plan written beforehand. After being given enough explanation about the material, the students of the experimental group were asked to do and submit the writing exercises and tasks based on the pictures taken from instagram accounts. The researcher assessed and gave feedback to the submitted writing works. The complete schedule of the treatment was presented in the following table:

Table 1. Schedule of the treatment

\begin{tabular}{|c|c|c|c|}
\hline Meeting & Time & Material & Group \\
\hline 1st & $\begin{array}{l}\text { Friday, } 15^{\text {th }} \\
\text { September } \\
2017\end{array}$ & $\begin{array}{l}\text { Descriptive } \\
\text { Text }\end{array}$ & $\begin{array}{l}\text { Experimental } \\
\text { Group }\end{array}$ \\
\hline $2^{\text {nd }}$ & $\begin{array}{l}\text { Friday, } 22^{\text {th }} \\
\text { September } \\
2017\end{array}$ & $\begin{array}{l}\text { Descriptive } \\
\text { Text }\end{array}$ & $\begin{array}{l}\text { Experimental } \\
\text { Group }\end{array}$ \\
\hline $3^{\text {th }}$ & $\begin{array}{l}\text { Friday, } 29^{\text {th }} \\
\text { September } \\
2017\end{array}$ & $\begin{array}{l}\text { Descriptive } \\
\text { Text }\end{array}$ & $\begin{array}{l}\text { Experimental } \\
\text { Group }\end{array}$ \\
\hline
\end{tabular}




\begin{tabular}{clll}
\hline $4^{\text {th }}$ & $\begin{array}{l}\text { Friday, } \\
6^{\text {th }} \text { October }\end{array}$ & Descriptive & Experimental \\
& Text & Group \\
& 2017 & & \\
\hline
\end{tabular}

The pre-test and post test were given to both experimental and control groups. In both tests, the students from the two groups were asked to make a descriptive text. The text consisted of three short paragraphs. The writing works were assessed using a writing rubric

\section{RESULTS AND DISCUSSION}

Based on the research results and analysis, it was found out that there was significant difference in the writing skill between the students taught using instagram and the students taught without instagram. The following tables show the results of the research.

Table 2. Descriptive analysis of pre-test and post-test of experimental group and control group

\begin{tabular}{lcccc}
\hline \multirow{2}{*}{ Description } & \multicolumn{4}{c}{ Group } \\
\cline { 2 - 5 } & \multicolumn{2}{c}{ Experimental } & \multicolumn{2}{c}{ Control } \\
\cline { 2 - 5 } & Pre-test & Post-test & Pre-test & Post-test \\
\hline Mean & 63.08 & 80.04 & 64.76 & 76.68 \\
Median & 66.00 & 80.00 & 66.00 & 76.00 \\
Standard Deviation & 13.70 & 9.66 & 13.04 & 9.66 \\
Minimum Score & 40.00 & 60.00 & 40.00 & 56.00 \\
Maximum Score & 83.00 & 93.00 & 86.00 & 93.00 \\
Mean Differences & \multicolumn{2}{c|}{$\mathbf{1 6 . 9 0}$} & \multicolumn{2}{c|}{$\mathbf{1 1 . 9 2}$} \\
\hline
\end{tabular}

Table 2 shows difference as well as improvement of the mean score between the experimental and control groups. The experimental group's mean score increases 16.90 points, whereas the mean of the control group increases lesser with 11.92 points. Other differences are obviously found in the standard deviation score, the minimum score, and the maximum score gained. For the standard deviation, the experimental group decreases 4.04 points and the control group decreases 3.38. The minimum score in the experimental group improves 20 points and 16 points in the control group. The last, the experimental group gained 10 points for its maximum score while the control group could only reach 7 points.

From these descriptive analysis results data, it can be concluded that compared to control group, the students of the experimental group have better improvement. This can be seen from the mean differences of the experimental group which is 4.98 points higher than that of the control group's mean.

Besides descriptive analysis, an inferential analysis was done as well. This is done in order to know whether the distribution of the data is normal or not. In this research, the Kolmogorov-Smirnov method was used to test the data completed with SPSS 24. The inferential analysis of the experimental group show that on significance level of 0,05 , the pre-test results, the probability (sig.) of the data pre-test in the experimental group is higher $(0.242>0.05)$. The post-test also show the same results in which it is higher at the score of $0.782>0.05$. Thus, it can be said that the distribution data of pre test and post test in the experimental group are normal. The complete data of the inferential analysis results of the experimental group are shown through the table below.

Table 3. Normality test of the experimental group

\begin{tabular}{ccccc}
\hline \multicolumn{4}{c}{ Test of Normalitty } & \\
\cline { 2 - 4 } Group & Kolmogorov-Smirnov & Decision \\
& 1.027 & Df & Sig. & \\
\hline Pre-test of Experiment & .656 & 25 & .242 & Normal \\
Post-test of Experiment & \multicolumn{3}{c}{.782} & Normal \\
\hline
\end{tabular}


Table 4. Normality test of the control group

\begin{tabular}{ccccc}
\hline & \multicolumn{3}{c}{ Test of Normalitty } & \\
\hline & \multicolumn{3}{c}{ Kolmogorov-Smirnov } & \multirow{2}{*}{ Decision } \\
\cline { 2 - 4 } & Statistic & Df & Sig. & \\
\hline Pre-test of Control & .612 & 25 & .848 & Normal \\
Post-test of Control & 1.040 & 25 & .229 & Normal \\
\hline
\end{tabular}

Table 4 displays the results of the normality test of the control group. Based on the data displayed, it's obvious that the distribution data of both pre test and post test in the control group are normal. This can be seen from the increase in the gained score of both tests, which is $(0.848>0.05)$ and $(0.229$ $>0.05$ ) respectively.
Another inferential analysis done is homogeneity test, which is done in order to know whether or not the score of one group has the homogeneous variance with the score of the other group's score. The group is called to be homogeneous if the value of the Fobserved $\left(\mathrm{F}_{0}\right)$ is lower than F-table $\left(\mathrm{F}_{\mathrm{t}}\right)$. The result of the homogeneity test of the research is illustrated through the following table.

Table 5. Test of homogeneity

\begin{tabular}{cccc}
\hline Variable & $\mathbf{F}_{\mathbf{0}}$ & $\mathbf{F}_{\mathbf{t}}$ & Interpretation \\
\hline Pre-Test & 1,104 & 1,984 & Homogeneous \\
Post-Test & 1,001 & 1,984 & Homogeneous \\
\hline
\end{tabular}

Based on the table 5, it is found that the value of $F_{0}$ is lower than $F_{t}$ for both variables. The value of $F_{0}$ for the pre test is 1,104 and the value of $F_{0}$ for the post test is 1,001 . Both values are lower than the value of $\mathrm{F}_{\mathrm{t}}$, that is1.984. Thus, it can be concluded that the sample of variance is homogenous.

Table 6. Test of hypothesis

\begin{tabular}{lccc}
\hline & $\mathbf{t}_{\mathbf{0}}$ & $\mathbf{t}_{\text {table }}$ & Interpretation \\
\hline Writing Score & 2.24 & 2.01 & Hypothesis Accepted \\
\hline
\end{tabular}

Table 6 shows results of the hypothesis testing. The $t$ value of the observation $\left(t_{0}\right)$ is compared with the $t$ value of the table $\left(\mathrm{t}_{\mathrm{t}}\right)$ in the significance level of $5 \%$. The $t$ value of the table is found from the degree of freedom $\left(\mathrm{d}_{\mathrm{f}}\right)$. In this research, the $d_{f}$ of the two tests were found by subtracting the number of cases $(\mathrm{N})$ of the two tests by 2. After that, it is checked with the table at the significance level of $5 \%$, which then came to the $\mathrm{d}_{\mathrm{f}} 48$ value of 2.01 . In finding out the value of the $t_{0}$, the researcher used calculation as follow:

$$
\begin{aligned}
t_{\text {test }} & =\frac{M d_{2}-M d_{1}}{\sqrt{\frac{5 d_{1}^{2}}{N_{1}}+\frac{s_{d 1}^{2}}{N_{2}}}} \\
t_{\text {test }} & =\frac{16,96-11,92}{\sqrt{\frac{6,708^{2}}{25}+\frac{9,030^{2}}{25}}}
\end{aligned}
$$

$$
\begin{aligned}
& t_{\text {test }}=\frac{5,04}{\sqrt{\frac{44,993}{25}+\frac{81,540}{25}}} \\
& t_{\text {test }}=\frac{5,04}{\sqrt{1,800+3,262}} \\
& t_{\text {test }}=\frac{5,04}{\sqrt{5,062}} \\
& t_{\text {test }}=\frac{5,04}{2,250}=2,240
\end{aligned}
$$

Based on the calculation results, it can be seen that the $t$ value of the test is 2.24 and the $t$ value of the table is 2.0. It means that the $t_{0}>t_{t}$ $(2.24>2.01)$. Therefore, the proposed hypothesis is accepted. In other words, there's a significant difference in the students' writing ability between those taught using instagram and those taught without instagram. In general, 
the students' scores of experimental group were higher than that of the students' scores of control group. It is proved by the post-test mean score of experimental group which was higher than the post-test mean score of control group at the point of 80.04 and 76.68. Therefore, it can be concluded that that the use of instagram is effective in teaching students' writing descriptive texts.

\section{CONCLUSION}

In sum, instagram is an effective and suitable strategy to use in an English as a Foreign Language learning setting, particularly in learning writing descriptive texts. The attained outcomes of this research illustrate that after being taught using instagram, the experimental students who got the treatment of instagram media outperformed those from the control class who were treated without instagram use.

\section{REFERENCES}

Allyn, P. (2015). Top 5 reasons writing is important for kids on NBC's education nation.

Aryanti. (2016). The teaching of EFL writing in Indonesia. E-Journal of Graduate Program of Pendidikan Ganesha University, 16(2).

Dantes, et al. (2013). The investigation of the teaching of writing at the tenth grade of senior high school (SMAN) 1 aikmel in East Lombok. E-Journal of Graduate Program of Pendidikan Ganesha University, 1.

Kearney, M. S. (2012). Viewing mobile learning from a pedagogical perspective. Research in Educational Technology, 20(1), 1-17.

Listiani, G. (2016). The effectiveness of instagram writing compared to teacher centered writing to teach recount text to students with high and low motivation (The case of eight grade students in SMP Kesatrian 1 Semarang in the academic year of 2015/2016). Journal of English Language Teaching.

Viberg, O. (2013). Cross cultural analysis of users' attitudes toward the use of mobile devices in second and foreign language learning in higher education: A case from Sweden and China. Computers \& Education, 69, $169-$ 180. 